\title{
A metatheory of e-government: Creating some order in a fragmented research field
}

\author{
Albert Meijer ${ }^{\mathrm{a}, *}$, Victor Bekkers ${ }^{\mathrm{b}}$ \\ a Utrecht University, Bijlhouwerstraat 6, 3511 ZC Utrecht, Netherlands \\ ${ }^{\mathrm{b}}$ Erasmus University Rotterdam, Netherlands
}

\section{A R T I C L E I N F O}

Available online 12 May 2015

Keywords:

E-government

Metatheory

Literature review

Philosophy of science

\begin{abstract}
A B S T R A C T
Theoretical fragmentation in e-government studies hampers the further development of this field of study. This paper argues that a metatheory can reduce theoretical confusion. Ideas from the philosophy of the social sciences are used to develop a metatheory of e-government consisting of three dimensions: explaining/understanding, holism/individualism and change/maintenance. This metatheory is used to analyze a corpus of papers on egovernment in both journals on public administration and information systems. The analysis of the 116 papers shows a bias towards explaining e-government (rather than understanding social constructions), analyzing holistic systems (rather than the behavior, attitudes and cognitions of individual actors) and studying incremental rather than transformational change. We conclude that the value of the metatheory lies in (1) facilitating debate about e-government between researchers with different perspectives, (2) enabling researchers to be clear about their social science perspective, and (3) developing educational programs that bring in various scientific perspectives.

(c) 2015 Elsevier Inc. All rights reserved.
\end{abstract}

\section{Introduction}

In the last decades, information and communication technology (ICT) has altered public administration by transforming internal (business and policy) processes and external interactions. Garson (2006) provides an enlightening overview of the use of ICT in government over 70 years and highlights that the use of these technologies started in a specific set of organizations to digitize and streamline internal processes to develop into general usage by all government organizations to re-structure external information relations. The use of innovative new channels has been a key development of e-government in the past decade (Reddick \& Anthopoulos, 2014). Policy makers and scholars from different backgrounds have labeled this transformation as electronic government or e-government. E-government as a set of techniques is an important driver for the modernization of the public sector and egovernment as a practice can be described as the use of ICT in order to design new or to redesign existing information processing and communication practices in order to achieve a better government, especially in the field of electronic service delivery to companies and citizens but also for managerial effectiveness, and the promotion of democratic values and mechanisms (OECD, 2003; Moon, 2004; Gil-Garcia \& Pardo, 2005). ${ }^{1}$

\footnotetext{
* Corresponding author.

E-mail addresses: a.j.meijer@uu.nl (A. Meijer), bekkers@fsw.eur.nl (V. Bekkers).

${ }^{1}$ We realize that the term 'e-governance studies' would be a more appropriate term since much of our academic research is about governance rather than government. However, the term e-government has become institutionalized in the names of journals and conferences. For this reason, we have chosen to use the term e-government in this paper.
}

In the slipstream of this practice, the specific research domain of $e$ government studies has emerged, although the scholarly interest for ICT in public administration exists much longer (e.g. Kraemer \& King, 1986; Snellen \& van de Donk, 1998). Some claim that this relatively new field of scholarly attention lacks scientific rigor and is undertheorized (e.g. Grönlund \& Andersson, 2006; Margetts, 2009; Bekkers, 2012), while Yildiz (2007: 646) stresses the "definitional vagueness of the e-government concept". On the other hand, in many studies an instrumental - managerial and project - orientation prevails which has contributed to the rather descriptive nature of these studies (for a critical discussion: Bekkers \& Homburg, 2007; Heeks \& Bailur, 2007; Dawes, 2008). As such Scholl (2006) states that e-government studies are rather over-theorized than under-theorized. He argues therefore that egovernment studies are fragmented which results in conceptual confusion (see also Pollitt, 2011: 380-381; Yildiz, 2007: 650, 651). The conceptual confusion hampers academic debates and scientific progress but also impairs the contribution of e-government studies as an academic field to society.

Given this fragmentation of e-government studies, Scholl (2006) calls for a more integrative approach (see also Pollitt, 2011; Dawes, 2008). Following up on this call, this article attempts to create some order in the fragmented research field by introducing a metatheoretical framework. A metatheory presents a systematic overview of the more or less conscious or unconscious assumptions behind different sorts of theoretical, empirical, and practical work (Hjorland, 1998). It helps to reduce conceptual confusion by providing a framework that can be used to position various approaches as well as to understand their immanent strengths and weaknesses. The overall goal is to contribute to 
the maturity of the field of e-government studies by providing a foundation in terms of ontological and epistemological assumptions for the different approaches to e-government studies. A metatheory can be used to map the variety in approaches and possibly identify the dominance of certain approaches and the neglect of others. We have formulated the following research questions for our research:

1. How can we develop a metatheory of e-government to map the different ontological and epistemological approaches to this field of study?

2. Do we recognize all the approaches that the metatheory predicts in recent publications on e-government and can we identify patterns of dominance and neglect?

In order to answer the first question, we identify the major ontological and epistemological positions and traditions in the social sciences as the basis for this metatheory (Section 2). Following Hollis (2007) and Burrell and Morgan (1979) we distinguish positions that try to explain and understand the nature and outcomes of social actions and we illustrate how these traditions are used in e-government studies on the basis of a number of classical studies. The next step is to use this metatheory for systematically categorizing research on e-government. The methodological strategy that is used to analyze the current body of egovernment studies is sketched in Section 3. Section 4 presents the results of our systematic literature review. The analysis highlights that nearly all combinations of positions can be discerned but there is an emphasis on papers that focus on explaining incremental changes. In Section 5 a conclusion is formulated and an agenda is presented. We argue to improve research from positions that are neglected as well as to pay more attention to metatheory in educational programs in order to teach students about the different positions in e-government research.

\section{A metatheory of e-government}

\subsection{A metatheoretical cube with three dimensions}

Yildiz (2007: 647, 648) describes how the study of e-government started in the 1960s and evolved into a full fletched field of study in the first decade of this millennium. The variety in approaches that have been developed can be - and have been - organized in different manners. One can, for example, focus on activity domains of electronic government activity (such as e-government, e-democracy, e-participation, e-procurement, e-auctions, e-policy, etc.) or on disciplinary perspectives (legal, technological, financial, managerial, political). This paper, however, aims to distinguish approaches in terms of their assumptions and ambitions for knowledge production about e-government. For a fundamental assessment of ontological and epistemological assumptions in order to develop an e-government metatheory, we will use different social science perspectives.

A metatheory is a theory whose subject matter is other theories in a specific research domain in order to understand what different traditions and positions are, what the role of knowledge is and how it can be obtained, and what the basic assumptions behind these traditions and positions are (Fiske, 1986). In our case the subject matter are the different theories that are used in e-government studies. A metatheory 'works' when it succeeds in presenting a systematic overview of key differences between various theoretical approaches.

Hjorland (1998: 607) indicates that different ontological and epistemological positions form the basis for metatheories in the social sciences. Metatheoretical perspectives have been developed for such diverse disciplines as sociology (Ritzer, 1988), information science (Hjorland, 1998), management science (Tsoukas, 1994) and family studies (Klein \& Jurich, 1993). A basic metatheory of e-government is proposed by Heeks and Bailur (2007) who make a distinction between positivist and social constructionist studies. Our metatheoretical framework regards this distinction as one relevant dimension but also identifies two other dimensions and, as a consequence, our metatheory will take the form of a cube with three dimensions that we have distilled from the literature (see Fig. 1). In doing so we will use Hollis (2007) as well as Burrell and Morgan (1979) as our major source of reference to understand the different ontological and epistemological positions in social sciences.

The three dimensions of this cube will be illustrated and developed further on the basis of classical papers in e-government studies.

\subsection{Dimension 1 'Research ambition': explaining - understanding e-government}

The first dimension of our metatheory, explaining versus understanding e-government, is similar to Heeks and Bailur's (2007) distinction between positivist and social constructionist studies. This distinction refers to the ambition of scientific work: explaining or understanding. Explaining is generally regarded as providing an account of a phenomenon on the basis of an outsider's perspective while understanding takes the actor's perspective as the central focus of the account (Hollis, 2007: 16, 17). Hollis (2007: 17, 18) stresses that more mechanical terms such as 'agents' and 'systems' are used for explaining while the terms 'actor' and 'game' are used for understanding to emphasize that human beings are not guided by external rules but actively attribute meanings. When we apply this distinction to understand the foundations of e-government studies, then explaining as a perspective is characterized by a focus on key variables of e-government such as technology, work processes or organizational structure. The ambition is to identify more general patterns or 'laws'. However, understanding implies studying the meanings that are given to processes and artifacts. The ambition is then to find out how (local) meanings are constructed in social interactions which eventually may lead to a shared understanding (Heeks \& Bailur, 2007: 249, 250).

A key example of the focus on explaining is the application of Rogers (2003) theory about the diffusion and adoption of innovations to studying e-government. From this perspective the maturity of e-government is viewed in terms of a specific adoption rate, in which stages of adoption are being distinguished in combination with specific adopter categories. A related line of thinking is found in so-called stage models of egovernment. These models build upon Nolan's (1979) classical work and embrace the idea that e-government development follows a stage-model. The model starts with being present on the web, which evolves into vertical and horizontal integrated services that leads to a transformation of government in terms of forms of whole joined-up

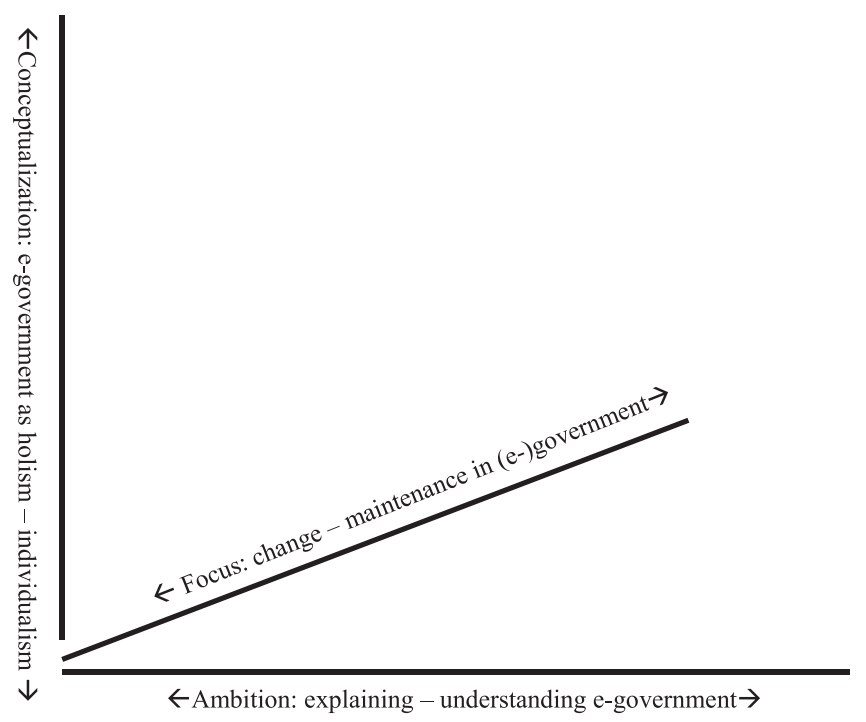

Fig. 1. Overview of different approaches to e-government studies. 
government (Layne \& Lee, 2001; Heeks \& Bailur, 2007:55; Gil-Garcia \& Martinez-Moyano, 2007). These models lack attention for context and behavior of specific actors but propose that forms of e-government can be explained in terms of the diffusion of technologies and the stage - in terms of maturity - that governments have reached.

Research with the ambition to strengthen our understanding of egovernment has a strong focus on context and on the meanings attributed to new technologies (Pinch \& Bijker, 1987). A powerful example of this position is Fountain's (2001) technology enactment framework which implies that the capabilities and potential of ICT are enacted by many organizational actors that are aware of this potential. Technology enactment is the result of cognitive, cultural, structural and political embeddedness. As a result of this embeddedness the change that occurs has to deal with the influence of specific socio-structural mechanisms (like existing rules, routines, norms and power relations) that are present in specific organizational and institutional arrangements (Fountain, 2001). Similarly, Heeks (2002) study of ICT and government in developing countries helps to understand the contextual and emergent nature of success and failure: The assumption is that cases from developing countries provide fertile ground for helping to understand the complex interplay of action and context that underlies organizational change. Fountain's (2001) and Heeks (2002) approaches help to understand forms of e-government in specific contexts.

\subsection{Dimension 2 'E-government conceptualization': holism-individualism}

According to Hollis (2007:12) holism refers to approaches that account for individual agents by appeal to some large whole, while individualism refers to an approach which accounts for structures by appeal to individual agents or actors. A holistic approach of egovernment implies a focus on e-government as a social structure, a social order or even a social system, which consists of mutually dependent elements that fulfills specific functions, coordinated in a proper way to achieve specific goals (Hollis, 2007:95). In this approach, social facts like crime, bureaucracy but also e-government - exist externally to individuals. However, a more individualistic approach implies that the researcher focuses on the behavior of individual agents or actors (Hollis, 2007:15): the emergence of e-government as a social structure is perceived as the outcome of choices of officials, politicians, clients, etc.

The resource dependency perspective on the role of technology in and between organizations (Pfeffer \& Salancik, 1978; Kumar \& Van Dissel, 1996) is an example of an individualistic approach to egovernment. E-government can therefore be seen as the outcome of resource politics (Kraemer \& King, 1986). This idea has been elaborated in several directions. First, it implies that ICT and information is seen as a powerful resource that actors use to reduce uncertainty and dependency in their interactions with other actors. ICT influences how access, exchange and processing of information as well as the distribution and sharing of information is organized. Secondly, ICT as a powerful resource is also used to control other resources, like personal and finance. Thirdly, ICT involves the substantive investments (applications, infrastructure, personnel etc.) that influence the allocation of money. This implies that the control over ICT, information and communication as resources opens the door for the specific actor to exercise power. That is why the shaping of e-government can be seen as the outcome of process of 'information politicking' (Knights \& Murray, 1992).

The evolutionary approach of information systems is an example of the holistic approach. Scholars (e.g. Nardi \& O'Day, 1999; Davenport \& Prusak, 1997; Bekkers \& Homburg, 2005) try to understand the changes that occur, from an ecological perspective. Dunleavy, Margetts, Bastow, and Tinkler (2005) argue that the nature of e-government can be understood as the co-evolution of technological developments with organizational changes in public administration, the embracement of new managerial and governance ideologies and changes in the information behavior in society. Holistic approaches have also been used to study changes in government bureaucracy. Zuurmond's (1994) 'infocracy' refers to a paradigm shift from a Weberian reified physical structure of knowledge processing, as a basis for the functions and activities, to a knowledge repository that act as a somewhat indistinct window of opportunity for all kinds of functions and activities that cross organizational borders. Bovens and Zouridis (2002) have demonstrated that due to the dominant role of ICT in the handling of individual cases, street level bureaucracies has changed into system level bureaucracies. These approaches are quite diverse but they all focus on egovernment as a holistic system that transforms through the use of new technologies instead of being the outcome of the individual choices of various actors.

\subsection{Dimension 3 'Research focus': change - maintenance in (e-)government}

The distinction between change and maintenance (Burrell \& Morgan, 1979) refers to Heraclitus' old discussion of seeing social reality as stable or in a continuous flux. On the one hand, scholars try to understand social phenomena by pointing at the underlying unity, cohesiveness and continuity and the importance of gradual changes and adjustments of the status quo (Burrell \& Morgan, 1979:17). On the other hand, scholars stress the importance of radical change as being characteristic for society (Burrell \& Morgan, 1979:17). They emphasize that research needs to identify the key differences between egovernment and previous forms of government. The discussion between change and maintenance refers to a discussion which touches upon the innovative power of e-government, and the nature of the learning process behind it (Bekkers, 2012).

Some key publications in the field of e-government studies focus on the radical changes induced by new technologies. Sometimes this radical change is framed in terms of the emergence of the information society (Chadwick \& May, 2003) or the network society (Castells, 1996). When applied to the realm of government some scholars talked about the coming of the 'information polity': the emergence of new institutional arrangements in which existing flows of information and relationships are rearranged while new flows, new types of intelligences and new relationships are being established, thereby crossing all kinds of boundaries (Bellamy \& Taylor, 1994, 1998). In a broader sense, Zuboff (1988) argues that, as such, the introduction of ICT lead to an immanent change in the way organizations process information that enhances the reflexivity of organization, stressing the informating capacities instead of automating capacities of ICT.

Other scholars focus their research on the maintenance of old structures. Frissen (1999), for example, shows how the 'Wahlverwantschaft' between ICT and bureaucracy helps to strengthen bureaucracy since the use of ICT presupposes standardization and formalization in order to function properly. Also the reinforcement hypothesis regarding the role of ICT in American local government reflects the idea of maintenance (Danziger, Dutton, \& Kraemer, 1982; Kraemer \& King, 1986). The argument is that the form that technology takes, reflects pre-existing system characteristics (Dutton \& Kraemer, 1979). This implies that present egovernment initiatives follow an already existing trail: they built upon grown practices and established interests that can only be understood when taken into account the history, the power relations and the dominant culture (like beliefs and even ideology) of the involved organizations or policy sector into account (Kling, 1987; Mason, McKenny, \& Copeland, 1997).

\subsection{Metatheory as basis for mapping ontological and epistemological assumptions}

On the basis of this discussion of the literature, we can now answer our first research question: how can we develop a metatheory of e-government to map the different ontological and epistemological approaches to this field of study? Building upon both the philosophy of the social sciences (Burrell \& Morgan, 1979; Hjorland, 1998; Hollis, 
2007; Heeks \& Bailur, 2007; Scott \& Davis, 2007) and a variety of more or less classical papers in e-government - and related - studies (Nolan, 1979; Dutton \& Kraemer, 1979; Kling, 1987; Zuboff, 1988; Dutton \& Guthrie, 1991; Orlikowski, 1991; Davenport \& Prusak, 1997; Nardi \& O'Day, 1999; Fountain, 2001; Layne \& Lee, 2001; Bovens \& Zouridis, 2002; Bekkers \& Homburg, 2007; Chadwick \& May, 2003; Dunleavy et al., 2005; Margetts, 2009), we developed a metatheoretical cube that consists of three dimensions: (1) explaining versus understanding, (2) holism versus individualism and (3) maintenance versus change. We claimed that the diversity of ontological and epistemological assumptions in the field of on e-government could be mapped on the basis of these three dimensions. This claim will be tested in a systematic review of the literature.

\section{Research methods}

\subsection{Aims of the systematic literature review}

We conducted a systematic review of recent literature on egovernment to attain the following two goals: 1 ) investigate the validity of our metatheory and 2) explore the current orientations in egovernment studies. To realize these goals, we systematically selected a set of publications and analyzed this body of recent e-government publications based on a categorization scheme that we developed from the three dimensions of our metatheoretical cube. The advantage of this type of systematic review is the review process and its outcomes become transparent and can be reproduced (Transfield, Denyer, \& Smart, 2003). The result of the selection process leads to a number of eligible studies that meet the selection criteria. Hence, it is not the number of studies that are being analyzed that counts in order to be representative. Most important is the eligibility of the studies, given the selection criteria because they define the corpus of the publications to be studied.

\subsection{Selecting a corpus of publications}

The body of literature we selected, is the result of a series of methodological choices. First, we chose to focus on journals within the research fields that are most relevant for e-government studies, Information Science and Public Administration, and we excluded journals that pay attention to only technological aspects of e-government. For Information Science, we included the three peer-reviewed journals that are commonly seen as the most focused, established and prestigious journals on e-government studies: Government Information Quarterly, Information Polity and Social Science Computer Review. For Public Administration we included a higher amount of journals, as in that field of study, research on e-government is more dispersed. We included all the top journals in the field of public administration: American Review of Public Administration, Public Administration Review, Journal of Public Administration Research and Theory, Administration Society, Public Administration, International Review of Administrative Sciences, Local Government Studies and Governance and Public Management Review. We chose not to include journals from related disciplines such as political science and organizational science since this would result in the inclusion of articles that are either more on democratic and political aspects of ICT and government or on use of new technologies in private organizations.

Second, we selected articles from between 2011 and 2013 to investigate the current state-of-the-field in e-government studies. We found the articles with the use of two databases: Scopus and Social Science Citation Index. We realize that interesting and relevant articles are published in other journals but our key aim was to develop a systematic design based on established high quality publications. For this reason, we chose to limit our search to journals ranked in these two databases. In both databases we searched using the term 'e-government' within the selection of journals and years. This search resulted in a total of 151 articles. After a quick scan, we reduced the selection by excluding the articles that did not present empirical research. We chose to insert only empirical articles to assess specific epistemological and ontological trends in ongoing research. This resulted in a set of 116 articles for the central analysis. To map this corpus, we coded the articles for country of first author, country of study, year of publication, journal, field of study and number of citations. Furthermore, we coded for whether the articles presented a case study or comparative study and whether the research method was quantitative, qualitative or mixed.

\subsection{Describing the corpus}

The corpus consisted of 29 articles published in journals in Public Administration and 87 articles published in Information Science journals. Within these two groups, Public Administration Review and the American Review of Public Administration had published most articles in the group of Public Administration (PA) journals. Government Information Quarterly was dominant in the group of Information Systems (IS) journals and the two most cited papers were also published in GIQ. The overview of publications per journal is presented in Table 1 below.

The articles in the corpus were written by authors with affiliations from 29 different countries ranging from Brazil through South Africa to Kuwait. Although there is a wide diversity of researched countries present in the sample, American and European research is predominant (respectively $33 \%$ and $27 \%$ of all publications in the corpus).

The papers showed a variety in research method, although it must be stated that $65 \%$ ( 75 articles) is based on quantitative data methods (like surveys), 28\% (33 papers) on qualitative research (especially case studies) and $7 \%$ ( 8 papers) make use of mixed method strategy. Within the group of quantitative papers, there's an emphasis on model and framework building. The Technology Acceptance Model (TAM) for instance is a popular theoretical approach and there were also a substantial number of articles that focused on quantitative benchmarking frameworks.

Scholarly articles on e-government are being published in a variety of journals, they are written by authors from all around the world and different research methods are used to investigate e-government. However, it should be mentioned that there is certain dominance of quantitative papers published in Government Information Quarterly and written by American authors. In order to grasp a possible variety of scientific perspectives we analyzed this corpus on the basis of metatheoretical categories.

\subsection{Analyzing the publications}

We analyzed the articles in our corpus on the basis of the three dimensions of our metatheory of e-government. Reconstructing the scientific perspective is complicated since most publications do not contain a reference to concepts of research philosophy such as ontology, positivism, epistemology, paradigms, etc. (see also: Heeks \& Bailur, 2007). Hence, the analysis was done by searching for indicator words in

Table 1

Number of articles per journal.

\begin{tabular}{lc}
\hline Journal & Number of articles \\
\hline American Review of Public Administration (ARPA) & 6 \\
Public Administration Review (PAR) & 6 \\
Journal of Public Administration Research and Theory (JPAR) & 3 \\
Administration \& Society (AS) & 2 \\
Public Administration (PA) & 3 \\
International Review of Administrative Sciences (IRAS) & 3 \\
Local Government Studies (LGS) & 3 \\
Public Management Review (PMR) & 3 \\
Governance (Gov) & 0 \\
Government Information Quarterly (GIQ) & 77 \\
Social Science Computer Review (SSCR) & 3 \\
Information Polity (IP) & 7 \\
Total & 116 \\
\hline
\end{tabular}


context. This meant that we looked for words and sentences that indicated a certain orientation for one of the three dimensions and then we verified this indicator, by looking at the context in which these words or sentences were placed. For every dimension, it was possible that an article fitted neither side of the dimension, only one, or both. Alongside the coding, we kept a document with arguments for our choices with regard to the dimensions. It was often not easy to position the publications in one of the cells and often, after intense debates within our research team and admitting the limitations of our metatheory, we categorized the 'hard cases'.

\subsubsection{Measures (1): explaining versus understanding}

A focus on explaining e-government is identified when egovernment practices are conceptualized as being 'out there' and when the paper aims to produce objective knowledge. Indicators terms - to be understood within the context of the paper - are 'explanation', 'causal relation', 'correlation' and 'effect'. The study by Kyriakidou, Michalakelis, and Sphicopoulos (2012: 182) about factors that explain the uptake of public e-services in the EU is a clear example. A focus on understanding is identified when the article aims to understand meanings that are given by actors and focuses on subjective knowledge and indicator terms are '(social) construction' and '(local) meaning'. The research by Heflin, London, and Mueser (2012) that aims to elicit what the clients see as good/problematic in an online food assistance application system through in-depth interviews, observations and site visits is a clear example.

\subsubsection{Measures (2): individualism versus holism}

If the research wants to explain/understand a phenomenon by looking at individual factors, it is categorized as having an individualistic focus. Indicator terms - to be analyzed in context - are '(individual) perception', 'attitude' and 'behavior'. Research by Shyu and Huang (2011) into the usage of e-government learning with the Technology Acceptance Model as a theoretical frame is a clear example. A focus on holism means that the research wants to explain/understand a phenomenon by looking at structural factors. 'Institutions', 'structures' and '(organizational) forms' are indicator terms. Research by Luna-Reyes and GilGarcía (2011) that uses institutional theory to study e-government development in Mexico through a multi-method research approach is a clear example of a focus on holism.

\subsubsection{Measures (3): maintenance versus change}

Nearly all articles discuss some kind of change but the change perspective is reserved for transformative change that is actually studied and not only assumed in either the introduction or the conclusions. Transformative change is a change that entails the quality of certain social structure. Indicator terms for transformative change are 'reshaping', 're-structuring' and 'institutional change'. An example is the research by Heflin et al. (2012) that studies how the expansion of egovernment is reshaping the position of disadvantaged groups. The opposite is instrumental change, which entails only a quantitative change or a relocative change. The term maintenance is reserved for either a study of the status quo or of incremental change. Indicator terms are 'adoption', 'use', 'implementation' and 'acceptance'. An example is the work by Reddick and Norris (2013) into social media adoption.

\section{Analyzing the theoretical perspectives}

\subsection{Separate analysis of the three dimensions}

We investigated the scientific focus in all papers in our corpus on the basis of the three dimensions of our metatheory of e-government to see whether all the approaches that the metatheory predicts can be found in recent publications on e-government and whether we can identify patterns of dominance and neglect. The findings from our literature analysis are presented below in Figs. 2, 3 and 4.
Fig. 2 shows that 'explaining' is a very dominant perspective in the study of e-government (87.9\%). Many papers present, develop and test theoretical models. An example is Oliveira and Welch's (2013: 2) research into technology-task couplings: "Through regression analysis study aims to find which organizational factors can predict 'technology-task' couplings. This paper makes use of newly collected national survey data from local government managers in five different agencies to address the questions: which social media tools are being used, for which tasks or purposes; and what organizational characteristics influence the coupling of task and technology." Another example is Hung, Chang, and Kuo's (2013: 30) research into the acceptance of $\mathrm{m}$ services: "The purpose of this study is to identify the factors that determine user acceptance of these services. Based primarily on the theory of planned behavior and supplemented by the mobile communication perspective, a sample of 331 users of m-government services in Taiwan was tested. The findings show that perceived usefulness, perceived ease of use, trust, interactivity, external influence, interpersonal influence, self-efficacy, and facilitating conditions are critical factors."

We found the perspective of 'understanding' only in a few articles in the corpus (7.8\%) and these were mostly interpretative approaches. An example is Homburg et al.'s (2013: 1) research into the diffusion of personalized services: "Furthermore, the model shows how persuasive pressure (as perceived by adopters) is followed-up by organizational search activities, and how, in various circumstances, the idea of personalized services is 'framed' by innovation champions, knowledge brokers and new members of staff as to appeal to specific organizational priorities and ambitions". Furthermore, the concept of 'framing' seems to be of growing importance in papers that aim to enhance our understanding of e-government.

A few papers only described e-government practices and did not aim to either come to an explanation for or understanding of them (3.4\%). Finally, one paper presented a theoretical perspective that focused on both 'explaining' and 'understanding' (0.9\%). Andersen, Medaglia, and Henriksen (2012) use a mixed method, in which available data is quantitatively analyzed, but also workshops with practitioners and such are held to analyze in-depth what they see as the possible impact of social media use. In the former, the focus is on the explaining of patterns, while the latter focuses on the meanings the practitioners attribute to social media use.

We investigated the corpus to find out whether there was a difference between the publications in Public Administration (PA) journals as compared to the Information Systems (IS) journals. We did not find much difference: $7 \%$ of the publications in PA journals had a focus on 'understanding' and $8 \%$ of the papers in IS journals. Most of the papers with a focus on 'understanding' - 6 out of 9 - were published in Government Information Quarterly. This highlights that a focus on 'understanding' is a

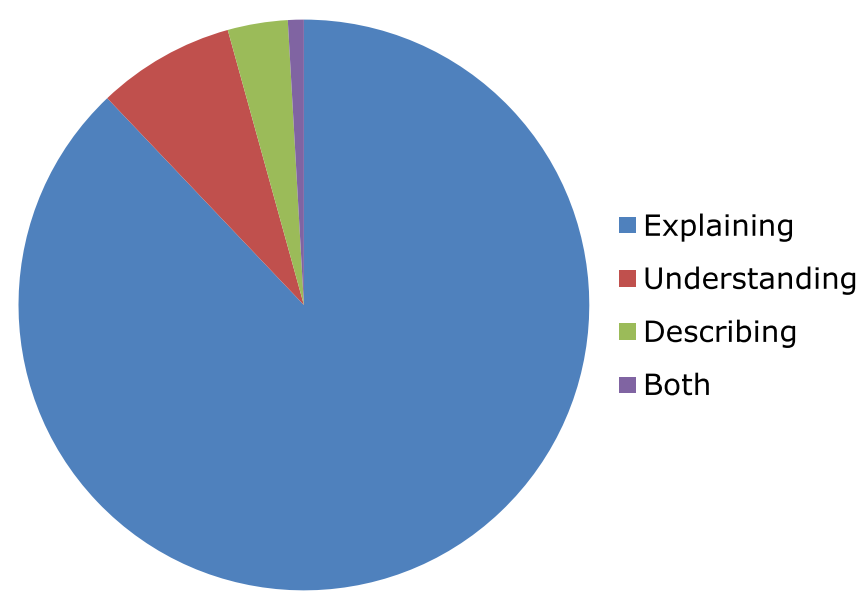

Fig. 2. Focus on 'explaining' or 'understanding' in e-government papers. 


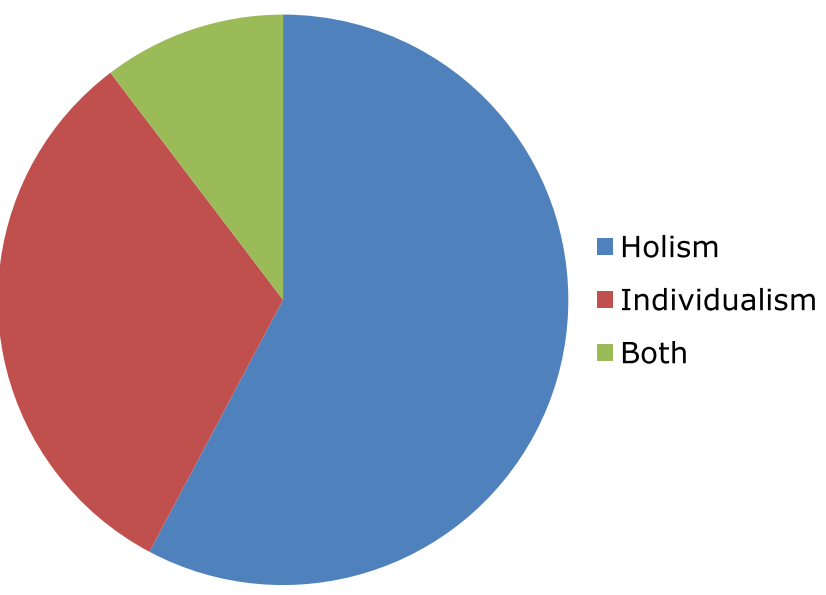

Fig. 3. Focus on individualism or holism in e-government papers.

minority position both in PA and IS journals: none of the journals had a strong focus on this perspective.

We also tested to what extent papers with these different foci get cited by other papers and we found that papers with a focus on 'understanding' are hardly cited: 6 papers were not cited at all and 3 papers were only cited by one other paper. This results in an average number of citations of 0.3 while the average number of citations for the papers with a focus on 'explaining' was 2 . The low number of citations seems to result from the fact that this is a smaller scholarly community. It was surprising to note that the paper with the highest number of citations presented a description rather than an explanation or an understanding.

Fig. 3 shows that most articles (57.8\%) have a holistic perspective. These articles focused on structure only and did not explicitly analyze how structures shaped behavior of individual actors. An example is Almazan and Gil-Garcia's (2012: 76) research into municipal websites: "The main objective of this research is to understand to what extent local government websites are including tools and strategies to foster interaction, participation, collaboration, and information sharing among government agencies and between government agencies and other social actors such as citizens, businesses, and non-profit organizations." There is no reference to various actors and their behavior but only to the overall form of e-government.

A substantive minority of the articles (31.9\%) had a focus on individual actors. Many of these articles focused on user perceptions of certain e-government practices and what leads them to adopt it. An example is

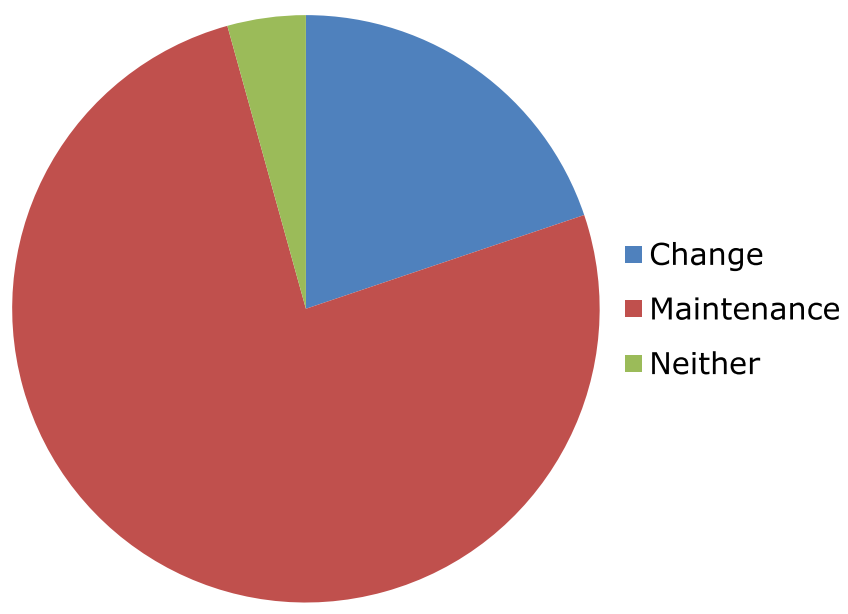

Fig. 4. Focus on maintenance or change in e-government papers.
Peacock, Moore, and Keene's (2013: 1115) research into information technology implementation practices in National Health Service hospitals: "We know relatively little about the ways in which informatics teams decide which systems to implement, and how they negotiate with clinicians, suppliers, senior managers and others in order to implement large scale systems - such as hospital-wide ordering systems - or link individual systems together." This research focuses on the interactions between teams to explain e-government outcomes.

Finally, there were also articles that presented both perspectives on e-government studies (10.3\%). An example is Rufín, Medina, and Sánchez (2012) research into the factors that influence citizens' intentions to use e-government. This research investigates the influence of both individual factors such as perceived ease of use and perceived compatibility and holistic factors such as the town's population size. The resulting use of e-government thus reflects a combination of individual and structural factors.

We analyzed the literature corpus for differences between PA and IS journals for this dimension of our metatheoretical framework. We found no great differences but overall the articles in PA journals presented slightly more individualistic (37.9\%) and combined perspectives (13.8\%) than the IS journals (29.9\% and 9.2\%). While we found variation in most journals, two journals - the International Review of the Administrative Sciences and Local Government Studies - only published papers with a focus on individual behavior. These findings highlight that the PA community has somewhat more interest in the individual actors whereas the IS community - as could be assumed by the name of the discipline - focuses more on the whole system.

We also tested whether there was a difference in the number of citations for papers in the different scientific perspectives. We found that the papers with a holistic perspective are cited somewhat more often than those with an individualistic perspective: an average number of citations of 2.4 versus 1.6 for the individualistic papers. There may be a network effect here: papers in larger communities are on average cited more often. This seems to be confirmed by the fact that the papers with an integrated perspective only get cited once on average.

Fig. 4 shows that only few papers focus on transformational change (19.8\%). An example is Lio, Liu, and Ou's (2011) work on the relation between e-government and the decrease in corruption. The study actually investigates this transformation by using a panel consisting of 70 countries covering the period from 1998 to 2005. The research highlights a statistically significant but not to substantial relation. The ambition of the research is clearly to investigate whether the alleged transformation effect can be found through a longitudinal and cross-country research design.

Most cases fell within the maintenance category (75.9\%). In the Introduction section many of these papers stress that ICT may have a transformational effect but in the actual research only incremental changes are investigated. Most of the maintenance articles do not study why governments stay the same, despite efforts to change it. They seem to assume - in the Introduction and the Conclusions sections - that instrumental change eventually results in transformational change and then continue to investigate instrumental change. A methodological reason may be that studying transformation change is more complicated and requires a long-term perspective. Armstrong's (2011) research into the transparency of local government websites, for example, focuses on the reproduction of pre-existing differences in professionalism and political orientation in school websites. The research shows how differences in e-government mirror structural differences between local governments.

A minority of articles discusses neither change nor maintenance (4.3\%). An example is Whitmore's (2012: 68) analysis of the construction of the United Nations E-Government Development Index: "This article evaluates the current standard in e-government ranking, the United Nations E-government Development Index, by performing a confirmatory factor analysis on the raw data reported in the 'Data tables' section of the 'Statistical annex' in the 2010 United Nations E- 
Government Survey." The study is not concerned with e-government as such, but more how it can best be measured.

Again, we analyzed whether there were differences between the PA and IS journal with respect to this dimension of our metatheoretical model. A slightly higher percentage of the papers in PA journals had a focus on transformation change than in IS journals (27.6\% versus $17.2 \%)$. An analysis of the specific journals showed that no journal had an exclusive focus on transformational change. Local Government Studies was the only journal with a majority of papers focusing on transformational change.

We tested whether there was a difference in the number of citations for the two perspectives and we found an average of 2.6 citations for the papers with a focus on transformational change and 1.8 on average for the papers focusing on maintenance or incremental change. These findings are not in line with the idea that a larger community results in a higher number of citations. This seems to indicate that papers focusing on transformational change are more likely to be cited than those focusing on incremental change since they generate more valuable insights for the (broad) scientific community.

\subsection{Analysis of the interactions between the dimensions}

Thus far, the dimensions were analyzed independently. To identify interactions between the dimensions, we analyzed whether certain combinations of perspectives were more likely than other combinations. There is a total number of 8 combinations and the scores for these combinations are presented in Table 2 (with $\mathrm{N}=97$ since all papers with other values on the three dimensions were excluded).

The table shows that nearly all combinations were present in the corpus, the only exception being the combination of a focus on understanding, holism and change. This perspective actually deals with the broad question of understanding transformational change in society. This would require a perspective from cultural sociology and one could argue that this type of question is often to encompassing for a specific research paper and more something to discuss in a book such as Castells (1996).

The combinations of 'explaining' and 'maintenance' accounts for over $70 \%$ of the papers in our corpus and this combination was both dominant in the PA and the IS journals with nearly exactly the same percentages. However, there were some interesting differences between the two communities. We found 5 papers with the combination of understanding, individualism and maintenance and these were only published in IS journals. In contrast, we found two papers with the combination of understanding, individualism and change and these were only published in PA journals. Individualism and change were also in combination with 'explaining' much more present in PA journals (11.5\%) than in IS journals (2.8\%). IS journals showed more emphasis on the combination explaining, holism and change.

\subsection{Patterns of dominance and neglect in e-government studies}

The metatheoretical framework was used to map the current stateof-the field in e-government studies. We selected a corpus of recent publications on e-government in both PA and IS journals. On the basis of the systematic literature review, we can now answer our second research question: do we recognize all the approaches that the metatheory predicts in recent publications on e-government and can we identify patterns of dominance and neglect?

The application of the framework highlighted that our metatheory was most useful for mapping the discipline. Overall, in the analysis of the 116 papers on e-government we found that there was a bias towards (1) explaining e-government (rather than understanding social constructions), (2) analyzing holistic systems (rather than the behavior, attitudes and cognitions of individual actors) and (3) studying incremental rather than transformational change. This bias was, for all three dimensions, slightly stronger in the IS journals than in the PA journals. At the same time it should be put forward that our results only take into account the recent period between 2011 and 2013. An interesting research question is to see if the emphasis in the articles is also present when taking a longer perspective and thereby also looking for interesting frame shifts in the scholarly approach.

Our systematic literature review confirms Heeks and Bailur's (2007) conclusion that certain perspectives on studying e-government receive very little attention. We have investigated their claim on the basis of a systematic literature review and conclude that most work concentrates on (1) explaining e-government rather than understanding egovernment as a social construction, (2) analyzing holistic systems rather than the behavior, attitudes and cognitions of individual actors and (3) studying incremental rather than transformational change. There is definitely a need for research that answers some of the questions that are not often dealt with in current research such as explaining how individuals transform government. The crucial question that none of the papers addressed was found in the combinations of understanding, holism and change: how do new technologies transform our social construction of government? Another crucial question is how to explain individual behavior in relation to a more profound understanding of the system of which these individuals are members. Hence, the dual relationship between the behavior of individual actors and systems and how this interplay influences the degree of change that egovernment establishes (e.g. Crozier \& Friedberg, 1980) is another weak spot in the present literature.

\section{Conclusions}

In this paper we have developed a metatheory of e-government that can help to create some order in the confusing debate about egovernment by explicitly highlighting ontological en epistemological positions. The metatheory that we developed consisted of three dimensions: research ambition, e-government conceptualization and research focus. We tested the value of this metatheory in a systematic literature review and we showed how the metatheory could be used to map the dominance of certain positions and the neglect of other approaches. This highlights the metatheory's value for organizing the theoretical fragmentation and enabling academic reflection. The specific value of the metatheory is threefold.

Firstly, the value of the metatheory lies in facilitating academic debate about e-government by providing a frame of reference. This frame of reference can for example be used to identify biases in our field of study. A

Table 2

Relations between the dimensions ( $\mathrm{N}=97)$.

\begin{tabular}{|c|c|c|c|c|c|c|}
\hline Dimension 1 & Dimension 2 & Dimension 3 & Number of articles & Overall percentage & Percentage in PA journals $(\mathrm{N}=26)$ & Percentage in IS journals $(\mathrm{N}=71)$ \\
\hline Explaining & Holism & Maintenance & 45 & $46.4 \%$ & $46.2 \%$ & $46.5 \%$ \\
\hline Explaining & Holism & Change & 13 & $13.4 \%$ & $7.7 \%$ & $15.5 \%$ \\
\hline Explaining & Individualism & Maintenance & 25 & $25.8 \%$ & $26.9 \%$ & $25.4 \%$ \\
\hline Explaining & Individualism & Change & 5 & $5.2 \%$ & $11.5 \%$ & $2.8 \%$ \\
\hline Understanding & Holism & Maintenance & 2 & $2.1 \%$ & $0 \%$ & $2.8 \%$ \\
\hline Understanding & Holism & Change & 0 & $0 \%$ & $0 \%$ & $0 \%$ \\
\hline Understanding & Individualism & Maintenance & 5 & $5.2 \%$ & $0 \%$ & $7.0 \%$ \\
\hline Understanding & Individualism & Change & 2 & $2.1 \%$ & $7.7 \%$ & $0 \%$ \\
\hline
\end{tabular}


key outcome of the mapping exercise was the dominance of the 'explaining perspective'. This functionalistic perspective emphasizes the system conditions under which ICT can operate in order to bring the desired change. In this perspective, ICT is an instrument to be managed and, as such, its role is not questioned: this instrument is regarded as something inherently 'valuable' when properly used. This normative bias towards e-government is also brought forward by other scholars (Bekkers \& Homburg, 2005, 2007). An important challenge for egovernment researchers is to look beyond the function of egovernment to reconstruct the implicit and explicit value propositions by analyzing how values are linked to other developments in public administration. Individual actors refer to the (hidden) values, influenced by individual interests and positions and the specific local and institutional context (Margetts, 2009). In doing so it is important to understand the political nature of the public sector (as a system characteristic) and the dynamics it creates in terms of influencing individual behavior (Bekkers \& Homburg, 2007; Margetts, 2009).

Secondly, the metatheory can help to communicate research perspectives more clearly when we report research findings. In our literature review we found that few researchers are explicit about their social science perspective. We challenge e-government researchers to be more explicit about their basic assumptions (for a similar plea: Heeks \& Bailur, 2007) and this metatheory can help to position their work. What is the e-government perspective that they work from? What is their epistemological perspective and ambition? Clearly positioning this work will help other researchers to understand and relate to their findings.

Thirdly, this metatheory can help universities to develop more balanced education programs for e-government studies. The metatheory can help to design educational programs for students of e-government that explicitly address the various scientific positions and teach students to ask questions about the premises of various research endeavors. The metatheory identified both more critical approaches and more prescriptive, change-oriented work as valid theoretical approaches. A broad understanding of e-government needs to form the basis for academic programs that train reflective engineers and consultants that do not only possess instrumental skills but are also trained in critical thinking.

\section{Acknowledgments}

We would like to thank Suzanne Potjer for her precise and systematic supporting work in conducting the analysis of the literature.

\section{References}

Andersen, K.N., Medaglia, R., \& Henriksen, H.Z. (2012). Social media in public health care: Impact domain propositions. Government Information Quarterly, 29(4), 462-469.

Armstrong, C.L. (2011). Providing a clearer view: An examination of transparency on local government websites. Government Information Quarterly, 28(1), 11-16.

Bekkers, V. (2012). Why does e-government looks as it looks? Looking beyond the explanatory emptiness of the e-government concept. Information Polity, 17(3-4), 329-342.

Bekkers, V., \& Homburg, V.M.F. (Eds.). (2005). The information ecology of e-government. Amsterdam: IOS Press.

Bekkers, V., \& Homburg, V. (2007). The myths of e-government: Looking beyond the assumptions of a new and better government. The Information Society, 23(5), 373-382.

Bellamy, C., \& Taylor, J. (1994). Introduction: Exploiting IT in public administration - Towards the information polity. Public Administration, 72(1), 1-12.

Bovens, M., \& Zouridis, S. (2002). From street level bureaucracy to system level bureaucracy. Public Administration Review, 62(2), 174-184.

Burrell, G., \& Morgan, G. (1979). Sociological paradigms and organisational analysis: Elements of the sociology of corporate life. London: Heineman Educational Books Ltd.

Castells, M. (1996). The rise of the network society. Cambridge: Blackwell.

Chadwick, A., \& May, C. (2003). Interaction between states and citizens in the age of the internet: E-government in the United States, Britain and the European Union. Governance, 26(2), 271-300.

Crozier, M., \& Friedberg, E. (1980). Actors and systems. Chicago/London: Chicago University Press.

Danziger, J.W., Dutton, R. Kling, \& Kraemer, K. (1982). Computers and politics. New York: Basic Books.
Davenport, T.H., \& Prusak, L. (1997). Information ecology: Mastering the information and knowledge environment. Oxford: Oxford University Press.

Dawes, S. (2008). The evolution and continuing challenges of e-governance. Public Administration Review, 68(8), 82-102.

Dunleavy, P., Margetts, H., Bastow, S., \& Tinkler, J. (2005). New public management is dead - Long live digital era governance. Journal of Public Administration Research and Theory, 16(3), 467-494.

Dutton, W., \& Guthrie, K. (1991). An ecology of games. The political construction of Santa Monica's public electronic network. Informatization and the Public Sector, 1(1), 279-301.

Dutton, W.H., \& Kraemer, K.L. (1979). The automation of bias: Computers and local government budgeting. Information Privacy, 1(7), 303-311.

Fiske, D. (1986). Meta-theory in Social Science. Chicago: University of Chicago Press.

Fountain, J.E. (2001). Building the virtual state: Information technology and institutional change. Washington, D.C.: Brookings Institution Press.

Frissen, P. (1999). Politics, governance and technology. Cheltenham: Edward Elgar.

Garson, G.D. (2006). Public information technology and e-governance: Managing the virtual state. Sudbury (MA): Jones \& Bartlett Publishers.

Gil-Garcia, R., \& Martinez-Moyano, I. (2007). Understanding the evolution of egovernment. The influence of rules on public sector dynamics. Government Information Quarterly, 24(2), 266-290.

Gil-Garcia, R., \& Pardo, T. (2005). E-government success factors: Mapping practical tools to theoretical foundations. Government Information Quarterly, 22(2), 187-216.

Grönlund, Ä., \& Andersson, A. (2006). E-gov research quality improvements since 2003 : More rigor but research (perhaps) redefined. In M. Wimmer (Eds.), Electronic government. Lecture notes of computer science (pp. 1-12). Heidelberg: Springer.

Heeks, R. (2002). Information systems and developing countries: Failure, success, and local improvisations. The Information Society, 18(2), 101-112.

Heeks, R., \& Bailur, S. (2007). Analyzing e-government research: Perspectives, philosophies, theories, methods and practice. Government Information Quarterly, 24(2), 243-265.

Heflin, C.M., London, A.S., \& Mueser, P.R. (2012). Clients' perspectives on a technologybased food assistance application system. The American Review of Public Administration, 43(6), 656-673.

Hjorland, B. (1998). Theory and metatheory of information science: A new interpretation. Journal of Documentation, 54(5), 606-621.

Hollis, M. (2007). The philosophy of social science. An introduction. Cambridge: Cambridge University Press.

Homburg, V., Dijkshoorn, A., \& Thaens, M. (2013). Diffusion of personalised services among Dutch municipalities: Evolving channels of persuasion. Local Government Studies, 40(3), 1-22.

Hung, S.Y., Chang, C.M., \& Kuo, S.R. (2013). User acceptance of mobile e-government services: An empirical study. Government Information Quarterly, 30(1), 33-44.

Klein, D.M., \& Jurich, J.A. (1993). Metatheory and family studies. In P.G. Boss, W.J. Doherty, R. LaRossa, W.R. Schumm, \& S.K. Steinmetz (Eds.), Sourcebook of family theories and methods (pp. 31-67). New York: Plenum.

Kling, R. (1987). Computerization as an ongoing social and political process. In G Bjerkness, P. Ehn, \& M. Kyng (Eds.), Computers and democracy (pp. 117-136). Aldershot: Ashgate.

Knights, D., \& Murray, F. (1992). Politics and pain in managing information technology: A case study in insurance. Organization Studies, 13(2), 211-228.

Kraemer, K., \& King, J. (1986). Computing and public organizations. Public Administration Review, 46, 488-496

Kumar, K., \& Van Dissel, H. (1996). Sustainable collaboration: Managing conflict and collaboration in interorganizational information systems. MIS Quarterly, 20(3), 279-300.

Kyriakidou, V., Michalakelis, C., \& Sphicopoulos, T. (2012). Utilization of communications network potential: Public practices and effects. Government Information Quarterly, 29(2), 182-191.

Layne, K., \& Lee, J. (2001). Developing fully functional e-government: A four stage model. Government Information Quarterly, 18(2), 122-136.

Lio, M.C., Liu, M.C., \& Ou, Y.P. (2011). Can the internet reduce corruption? A cross-country study based on dynamic panel data models. Government Information Quarterly, 28(1), 47-53.

Luna-Reyes, L.F., \& Gil-García, J.R. (2011). Using institutional theory and dynamic simulation to understand complex e-government phenomena. Government Information Quarterly, 28(3), 329-345.

Margetts, H. (2009). Public management change and e-government: The emergence of digital era governance. In A. Chadwick, \& P.N. Howard (Eds.), Oxford handbook of internet politics (pp. 114-128). Oxford: Oxford University Press.

Mason, R., McKenny, J., \& Copeland, D. (1997). An historical method for MIS research Steps and assumptions. MIS Ouarterly, 21(3), 307-320.

Moon, M. (2004). The evolution of e-government among municipalities: Rhetoric or reality? Public Administration Review, 64(4), 424-433.

Nardi, B., \& O'Day, V. (1999). Information ecologies. Cambridge Mass: MIT Press.

Nolan, R.L. (1979). Managing the crisis in data processing. Harvard Business Review, 57(2), $115-126$.

OECD (2003). The e-government imperative. Paris: OECD.

Oliveira, G.H.M., \& Welch, E.W. (2013). Social media use in local government: Linkage of technology, task, and organizational context. Government Information Quarterly, 30(4), 397-405.

Orlikowski, W. (1991). The duality of technology: Rethinking the concept of technology in organizations. Organization Science, 3(3), 398-427.

Peacock, R., Moore, J., \& Keene, J. (2013). Interim realities: Information technologies and unknown destinations. Public Management Review, 14(8), 1109-1124.

Pfeffer, J., \& Salancik, G.R. (1978). The external control of organizations. New York: Harper \& Row. 
Pinch, T., \& Bijker, W. (1987). The social construction of facts and artefacts. In W. Bijker, T. Hughes, \& T. Pinch (Eds.), The social construction of technological systems (pp. 17-50). Cambridge Mass: MIT Press.

Pollitt, C. (2011). Mainstreaming technological change in the study of public management. Public Policy and Administration, 26(4), 377-397.

Reddick, C.G., \& Anthopoulos, L. (2014). Interactions with e-government, new digital media, and traditional channel choices: Citizen-initiated factors. Transforming Government: People, Process and Policy, 8(3), 398-419.

Reddick, C.G., \& Norris, D.F. (2013). Social media adoption at the American grass roots: Web 2.0 or 1.5? Government Information Quarterly, 30(4), 498-507.

Ritzer, G. (1988). Sociological metatheory: A defense of a subfield by a delineation of its parameters. Sociological Theory, 6(2), 187-200.

Rogers, E. (2003). Diffusion of innovations (5th ed.). New York: Free Press.

Rufín, R., Medina, C., \& Sánchez, J.C. (2012). Moderating factors in adopting local egovernment in Spain. Local Government Studies, 38(3), 367-385.

Sandoval-Almazan, R., \& Gil-Garcia, J.R. (2012). Are government internet portals evolving towards more interaction, participation, and collaboration? Revisiting the rhetoric of e-government among municipalities. Government Information Quarterly, 29, S72-S81.

Scholl, H. (2006). Is e-government research a flash in the pan or here for the long shot? In M. Wimmer (Eds.), Electronic government. Lecture Notes of Computer Science, 13: 24, . Heidelberg: Springer.

Scott, W.R., \& Davis, G.F. (2007). Organizations and organizing: Rational, natural, and open systems perspectives. Englewood Cliffs: Pearson Prentice Hall.
Shyu, S.H.P., \& Huang, J.H. (2011). Elucidating usage of e-government learning: A perspective of the extended technology acceptance model. Government Information Quarterly, 28(4), 491-502.

Snellen, I., \& van de Donk, W. (Eds.). (1998). Public administration in an information age. Amsterdam: IOS Press.

Transfield, D., Denyer, D., \& Smart, P. (2003). Towards a methodology for developing. Evidence-informed management. British Journal of Management, 14, 207-222.

Tsoukas, H. (1994). What is management? An outline of a metatheory. British Journal of Management, 5(4), 289-301.

Whitmore, A. (2012). A statistical analysis of the construction of the United Nations egovernment development index. Government Information Quarterly, 29(1), 68-75.

Yildiz, M. (2007). E-government research: Reviewing the literature, limitations, and ways forward. Government Information Quarterly, 24(3), 646-665.

Zuboff, S. (1988). In the age of the smart machine. Oxford: Heineman.

Zuurmond, A. (1994). De infocratie. Rotterdam: Phaedrus.

Albert Meijer (1967) is a professor of public innovation at the Utrecht School of Governance. His research focuses on transparency, coproduction and social media.

Victor Bekkers (1963) is a professor of public administration at Erasmus University Rotterdam. He is also dean of Graduate School for the Social Sciences and the Humanities at the same university. 